\title{
Perancangan Strategis Perencanaan Sistem Informasi Menggunakan Zachman Framework dari Segi Planner
}

\author{
Rahmat Sulaiman \\ Mahasiswa Magister Komputer, Program Pasca Sarjana, Universitas Budi Luhur \\ Jl. Ciledug Raya, Petukangan Utara, Jakarta Selatan, DKI Jakarta 12260 \\ $\underline{\text { rs.rahmatsulaiman@gmail.com }}$
}

\begin{abstract}
Abstrak - Masalah dalam organisasi sering terjadi karena ketidak sesuaian posisi dengan kegiatan operasional yang dijalankannya. Dimana banyaknya tugas dan fungsi yang harus dilakukan suatu perusahaan menjadi landasan utama perlunya sistem informasi yang dibangun untuk mempermudah proses bisnis yang dijalankan oleh tiap-tiap karyawan yang ada. Zachman Framework merupakan salah satu EAP yang paling banyak digunakan dalam pembuatan perancangan perencanaan sistem infromasi yang sistematis. Langkah terstruktur yang disediakan Zachman Framework membuat perancangan perencanaan sistem informasi pengaturan kegiatan-kegiatan operasional pada organisasi secara global oleh menejemen operasional menjadi lebih sistematis dan deskriptif. Dengan menggunakan Zachman Framework dapat diperoleh infomasi secara detail tetang lingkungan sebuah sistem. Dengan Zachman Framework ini dapat membantu manajemen operasional sebuah organisasi atau instansi dalam penyusunan kewenangan SDM dalam kegiatan operasional yang berjalan.
\end{abstract}

Kata Kunci-Zachman Framework, Sistem Pengaturan Kegiatan Operasional

\section{Pendahuluan}

Tuntutan terhadap pengelolaan organisasi yang baik dan terstruktur agar terciptanya kerja sama dan hubungan yang baik dalam suatu perusahaan adalah salah satu kebutuhan yang harus disediakan oleh setiap perusahaan. Hal ini didasarkan pada kepentingan bersama demi mewujudkan visi dan misi setiap perusahaan. Dimana banyaknya tugas dan fungsi yang harus dilakukan suatu perusahaan menjadi landasan utama perlunya sistem informasi yang dibangun untuk mempermudah proses bisnis yang dijalankan oleh tiap-tiap karyawan yang ada.

Konflik merupakan warisan kehidupan sosial yang boleh berlaku dalam berbagai keadaan akibat daripada berbangkitnya keadaan ketidaksetujuan, kontroversi dan pertentangan di antara dua pihak atau lebih pihak secara berterusan.[1]

Informasi mengenai organisasi dan permasalahan yang tengah dihadapi oleh perusahaan diperoleh melalui studi Pustaka. Dengan adanya sistem informasi yang tepat diharapkan dapat menjadi solusi konkret dalam mengatasi masalah-masalah yang ada.

Permasalahan tersebut akan ditangani dengan sistem informasi yang disusun berdasarkan zachman framework. Zachman dipilih karena Enterprise Architecture ini dapat menggambarkan kondisi organisasi secara utuh (Erwin 2009) [2].

\section{TINJAUAN PUSTAKA}

\section{A. Perencanaan Strategis Sistem Informasi}

Perencanaan Strategis Sistem Informasi didefinisikan sebagai proses mengindentifikasi suatu pemetaan aplikasi berbasis computer yang akan membantu suatu organisasi dalam menjalankan perencanaan bisnisnya dan mewujudkan tujuan bisnisnya [4]. Perencanaan strategis sistem informasi meninjau kebutuhan organisasi dalam menjalankan proses bisnisnya, kemudian memanfaatkan teknologi informasi untuk membantu proses bisnis dan membuat suatu sistem informasi yang sesuai dengan kebutuhan organisasi.

\section{B. Pengelolaan Organisasi dan Sumber Daya Manusia dalam Bisnis}

Pembagian Departementalisasi secara fungsional biasanya, meliputi penempatan pegawai-pegawai yang melakukan fungsi atau proses kerja atau memiliki pengetahuan dan skill dalam satu departemen, misalnya departemen produksi (berarti orang-orang yang bekerja di dalamnya sama-sama melakukan proses produksi termasuk mulai dari pengolahan bahan baku, misalnya hingga pengemasan), pemasaran dan penjualan, akunting dan keuangan, Riset dan Pengembangan, serta Sumber Daya Manusia. Setiap bagian dapat dibedakan lagi menjadi subbagian. Keunggulan utama departementalisasi ini adalah tercapainya efisiensi karena menempatkan para spesialis di satu departemen. Keunggulan lainnya, antara lain berikut ini [3]:

1) Pencerminan logis dari fungsi-fungsi.

2) Mengikuti prinsip spesialisasi jabatan.

3) Memelihara kekuatan dan prestise fungsi-fungsi utama. 
4) Menyederhanakan latihan (karena tugas yang dilakukan relative berhubungan).

5) Sarana-sarana pengendalian ketat di tingkat puncak (mudah dikontrol).

\section{Enterprise Architecture}

Arsitektur enterprise merupakan aset perusahaan yang harus dikelola sebagai suatu program yang formal. Keberhasilan pelaksanaan proses EA adalah usaha instansi yang sangat memerlukan atau berketergantungan terhadap manajemen, alokasi sumber daya, kontinuitas, dan koordinasi. Eksekutif lini bisnis keagenan harus bekerja sama dengan tim arsitektur Instansi untuk menghasilkan deskripsi Instansi yang dibutuhkan, operasional, visi masa depan, dan strategi investasi dan teknologi untuk mencapai tujuan yang ditetapkan [5].

\section{Zachman Framework}

Zachman framework, dikeluarkan oleh Zachman Institut for Framework Advancement (ZIFA) sebagai hasil pemikiran dari John Zachman. Framework Zachman bukan sebuah metodologi karena framework ini tidak menyebutkan metoda dan proses spesifik untuk mengumpulkan. Hampir dua dekade yang lalu John Zachman, telah meningkatkan suatu bagan yang universal. Untuk melukiskan dan menggambarkan sistem perusahaan secara kompleks dimasa sekarang dan untuk mengatur berbagai perspektif dari suatu organisasi infrastruktur pengetahuan dan informasi [6]. Kerangka kerja Zachman dapat dilihat pada Gambar 1.

\section{ENTERPRISE ARCHITECTURE - A FRAMEWORK ${ }^{\mathrm{T}}$}

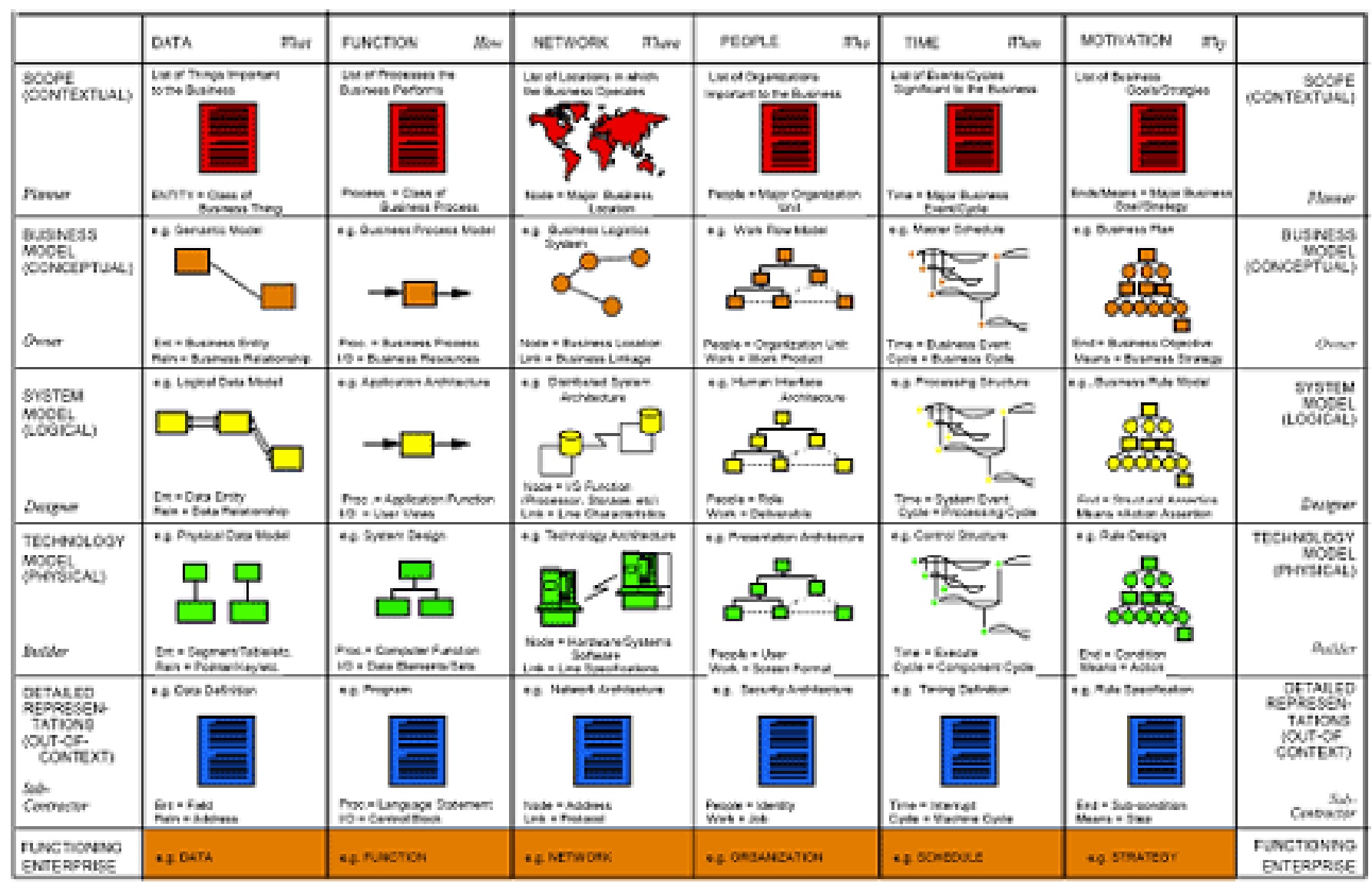

(C) $1986 \cdot 2005$ Joln A. Zachuma, Zacliman International

\section{See www.ZachmanInternational.com for 2005 Zachman Framework Standards}

Gambar 1. Zachman Framework

John Zachman mendefinisikan kolom dalam matriks untuk menggambarkan data, fungsi, lokasi (dimana bisnis berada), orang-orang yang seharusnya ada dan terlibat dalam organisasi, waktu untuk peristiwa yang terjadi, dan motivasi yang menentukan bagaimana bisnis berjalan. Kemudian, pada bagian baris digambarkan mengenai aspek-aspek development process yaitu: ruang lingkup, model bisnis, model sistem informasi, model teknologi, komponen model, dan sistem fungsi. 
Secara umum perspektif tersebut dibagi menjadi 6 baris [6] yaitu:

1) Scope (ruang lingkup): Biasanya dilihat dari sudut pandang perencana yang mendefinisikan arah enterprise dan tujuan bisnis.

2) Enterprise mode (model Perusahaan): biasanya dilihat dari sudut pandang pemilik perusahaan, mendifinisikan sasaran, strategi, struktur dan proses yang digunakan untuk mendukung sistem atau organisasi.

3) System model: berisi kebutuhan, obyek, aktifitas dan fungsi sistem dalam mengimplementasikan model bisnis. Dalam baris sistem ini kita dapat melihat detil pekerjaan.

4) Technologi model: mempertimbangkan batasan faktor manusia, alat, teknologi dan material. Sering disebut dengan baris fisik.

5) Detail representation: mewakili individu, komponen independen yang bisa dialokasikan pada kontraktor untuk implementasi.

6) Functioning enterprise: menggambarkan sistem operasional yang sedang dipertimbangkan sebagai salah satu solusi.

Secara umum hal tersebut dibagi menjadi 6 [7] :

1) What adalah komposisi bahan objek atau bahan-bahan untuk membuat model data.

2) How adalah spesifikasi fungsi bagaimana proses berjalannya model tersebut.

3) Where adalah lokasi komponen-komponen yang saling berhubungan satu dengan yang lainnya.
4) Who adalah orang yang melakukan operasional instruksi.

5) When adalah waktu pelaksanaan atau waktu yang akan digunakan dalam hubungan-hubungan siklus komponen yang ada.

6) Why adalah alasan menjelaskan motivasi dari organisasi dalam melakukannya.

\section{HASIL DAN PEMBAHASAN}

Berdasarkan penjabaran data yang ada diatas maka akan dilakukan pemetaan kedalam kerangka Zachman untuk menghasilkan rancangan sistem yang dibutuhkan. Kemudian akan diuraikan kedalam matrik kerangka Zachman dan dijabarkan tiap-tiap bagian

Berikut ini adalah penjabaran matrik Zachman dari hasil penelitian:

1) Kolom What

Menjelaskan tentang datang yang disediakan oleh sudut pandang Planner

2) Kolom How

Kolom ini membahas tetang proses kegiatan operasional organisasi

3) Kolom Where

Kolom ini membahas bagian Orgaisasi yang terkait

4) Kolom Who

Kolom ini membahas Sumber Daya Manusia (SDM) yang terkait

5) Kolom When

Kolom ini membahas tetang kejadian atau kegiatan berserta jadwalnya (kegiatan operasionalnya)

6) Kolom Why

Kolom ini menjabarkan tentang tujuan, visi danmisi organisasi

Tabel matrik zachman selengkapnya dapat dilihat ada tabel 1.

Tabel 1. Matrik Zachman Sistem Pengaturan Kegiatan Operasional

\begin{tabular}{|l|l|l|c|l|l|l|}
\hline Perspektif & \multicolumn{1}{|c|}{ What } & \multicolumn{1}{c|}{ How } & Where & \multicolumn{1}{c|}{ Who } & \multicolumn{1}{c|}{ When } & \multicolumn{1}{c|}{ Why } \\
\hline Scope & $\begin{array}{l}\text { Data } \\
\text { Organisasi }\end{array}$ & $\begin{array}{l}\text { Proses Kegiatan } \\
\text { Operasional }\end{array}$ & $\begin{array}{l}\text { Organisasi } \\
\text { (Global) }\end{array}$ & $\begin{array}{l}\text { Manajemen } \\
\text { Operasional }\end{array}$ & $\begin{array}{l}\text { Mengatur Bagian - Bagian } \\
\text { dan Fungsi tugas setiap } \\
\text { kegiatan operasional }\end{array}$ & $\begin{array}{l}\text { Visi dan } \\
\text { Misi } \\
\text { Organisasi }\end{array}$ \\
\hline $\begin{array}{l}\text { Business } \\
\text { Model }\end{array}$ & $\begin{array}{l}\text { Use Case } \\
\text { System }\end{array}$ & Activity Diagram & Organisasi & $\begin{array}{l}\text { Manajemen } \\
\text { Operasional } \\
\text { (SDM) }\end{array}$ & Time Schedule & $\begin{array}{l}\text { Pengadaan } \\
\text { Sistem } \\
\text { Informasi }\end{array}$ \\
\hline
\end{tabular}

Pada bagian ini matrik diatas akan diuraikan berdasarkan abstraksi perspektif atau sudut pandang planner saja.

\section{A. Perspektif Planner}

Baris pertama pada Zachman Framework ini sering disebut dengan arsitektur kontekstual. Pada arsitektur ini didefinisikan model bisnis fungsional secara global dan berbagai requirement external organisasi. Mendeskripsikan visi, misi, kontek, batas, dan arsitektur sistem. Sering disebut sebagai black box, karena kita dapat melihat input dan output, namun tidak dapat melihat detail pekerjaannya. Baris ini sering disebut baris konteks.

\section{1) What}

Kolom ini menerangkan tentang data-data atau entitas yang berkaitan dengan sistem informasi pengaturan kegiatan operasional sebuah organisasi. Berdasarkan hasil analisi data tersebut dikelompokan menjadi 1 bagian, yaitu: 
Sumber Daya Manusia, yaitu merupakan data pengelola atau pelaku kegiatan operasional. Beserta fugsi-fungsi tugas yang seharusnya.

2) How

Kolom ini membahas tentang proses-proses yang terjadi pada kegiatan operasional organisasi secara global. Proses utama yang terjadi adalah proses operasional harian:

Proses operasional harian:

a) Manajemen Operasional mengidentifikasi SDM yang ada

b) Manajemen Operasional membagikan dan mengdeskripsikan SDM yang berkaitan dengan kegiatan operasional Organisasi

\section{3) Where}

Kolom ini membahas tentang loasi bisnis utama yaitu membahas tentang Organisasi secara umum.

\section{4) Who}

Kolom ini Membahas tentang Sumber Daya Manusia yang berperan penting dalam proses pengaturan kegiatan operasional suatu Organisasi. Berikut ini adalah orang-orang yang berperan penting dalam proses tersebut:

a) Manajemen Operasional

b) SDM (Karyawan / Staff)

\section{5) When}

Pada kolom ini dijelaskan tentang kegiatan-kegiatan yang terjadi di suatu organisasi menurut pandangan planner. Untuk kegiatan utama yang akan dibahas adalah yang berkaitan dengan pengaturan kegiatan-kegiatan operasional. Adapun kegiatan-kegiatan tersebut adalah :

a) Pendataan karyawan

b) Pendeskripsian kemampuan karyawan

c) Pemetaan tempat yang sesuai dengan karyawan

6) Why

Pada kolom ini menjelaskan tujuan utama suatu organisasi. Dimana setiap organisasi menginginkan kegiatan operasional
Jurnal SISFOKOM, Volume 05, Nomor 01, Maret 2016

yang sistematis dan terstuktur untuk mencapai dan mewujudkan visi dan misi organisasi.

\section{PENUTUP}

\section{A. Kesimpulan}

Dari pembahasan yang sudah dipaparkan, maka peniliti dapat menarik beberapa kesimpulan:

- Dalam perancangan sitem pada penelitian ini dengan Zachman Framework harus menguraikan secara detail kolom dan baris pada matrik zachman yang telah diisi.

- Sangatlah penting untuk mengisi tiap-tiap kolom dan baris secara rinci agar dapat digambarkan dari berbagai pandangan,

\section{DAFTAR PUSTAKA}

[1] Taquiri. (1977). "Teori Konlik Organisasi".

[2] Erwin. (2009). "Pemilihan EA Framework".Seminar Nasional Aplikasi Teknologi Informasi2009.

[3] Astuti. R. D., "Pengelolaan Organisasi dan Sumber Daya Manusia dalam Bisnis", https://maradana.files.wordpress.com/2011/12/m3_nopw.pdf diakses pada tanggal 3 Agustus 2016.

[4] Ederer, A.L. \& Sethi, V. (1996) Key prescriptions for strategic information systems planning. Journal of Management Information Systems, 13 (1), 35-62.

[5] Chief Information Officer Council. (2001) ,"APractical Guide to Federal Enterprise Architecture".

[6] Antonius. W. S. (2015). “ Penerapan Framework Zachman Dalam Perancangan Arsitektur Sistem Manajemen Penyusunan Anggaran Keuangan Daerah (Studi Kasus UPTD Graha Teknologi Sriwijaya)". Citec Journal, Vol. 2, No. 1, November 2014 - Januari 2015 ISSN: 2354-5771.

[7] Zachman. J. A. (2003). "The Zachman Framework for Enterprise Architecture" http://www.businessrulesgroup.org/BRWG_RFI/ZachmanBook RFIextract.pdf diakses pada tanggal 1 Agustus 2016. 